\title{
Initial growth crown cover of cerrado species from different sucessional groups
}

\author{
Tatiane Forlin', Ana Paula Leite de Lima", Sebastião Ferreira de Lima'I", \\ Vespasiano Borges de Paiva Neto'v , Rita de Cássia Mariano de Paulav, Wesley \\ Gomes da Silvavi
}

\begin{abstract}
This study had the objective to evaluate the initial growth and crown cover of native cerrado species of different successional groups in planting forest restoration in Chapadão do Sul, MS, with an experiment installed in February of 2013 to test restoration models. Twelve species were selected, being four pioneers: Anadenanthera falcata, Cybistax antisyphilitica, Platypodium elegan and Samanea tubulosa; four early secondary species: Dipteryx alata, Sterculia striata, Alibertia edulis and Enterolobium contortisiliquum; and four late secondary species: Cedrela fissilis, Copaifera langsdorfii, Handroanthus roseo-albus and Hymenaea stilbocarpa. Diameter at soil height (DSH), total height and crown diameter were measured at 8, 14, 20 and 26 months after planting. the periodic increase in height and DSH were calculated by species, group and age, and the crown area at 26 months. The highest increases in height and DSH were from the pioneers group and from the early secondary until 26 months, and the lowest increases were from the late secondary species. The species within each group vary their initial investment in height and DSH. The pioneers group presented the largest crown areas, while the late secondary group presented the smallest.
\end{abstract}

Keywords: Recovery of degraded areas; Ecological succession; Growth

\section{RESUMO}

Com o objetivo de avaliar o crescimento inicial e a cobertura de copa de espécies nativas do cerrado de diferentes grupos sucessionais, em plantio de restauração florestal, em Chapadão do Sul, MS, foi instalado em fevereiro de 2013 um experimento testando modelos de restauração. Foram selecionadas 12 espécies, sendo quatro pioneiras: Anadenanthera falcata, Cybistax antisyphilitica, Platypodium elegan e Samanea tubulosa, quatro secundárias iniciais: Dipteryx alata, Sterculia striata, Alibertia edulis e Enterolobium contortisiliquum e, quatro secundárias tardias: Cedrela fissilis, Copaifera langsdorfii, Handroanthus roseo-albus e Hymenaea stilbocarpa. Foram mensurados o diâmetro à altura do solo (DAS), a altura total e o diâmetro de copa destas, aos 8, 14, 20 e 26 meses após plantio. Foi calculado o incremento periódico em altura e DAS, por espécie, grupo e idade e, a área de copa aos 26 meses. Os maiores incrementos em altura e DAS foram do grupo das pioneiras e das secundárias iniciais até os 26 meses e os menores das secundárias tardias. As espécies, dentro de cada grupo, variam seu investimento inicial em altura e em DAS. O grupo das pioneiras apresentou as maiores áreas de copa enquanto, as secundárias tardias as menores.

Palavras-chave: Recuperação de áreas degradadas; Sucessão ecológica; Crescimento

\footnotetext{
' Universidade Federal de Mato Grosso do Sul, Chapadão do Sul, Brasil - tatianef_@hotmail.com

" Universidade Federal de Mato Grosso do Sul, Chapadão do Sul, Brasil - paula.leite@ufms.br

I'I Universidade Federal de Mato Grosso do Sul, Chapadão do Sul, Brasil - sebastiao.lima@ufms.br

IV Universidade Federal de Mato Grosso do Sul, Chapadão do Sul, Brasil - vespasiano.paiva@univasf.edu.br

vUniversidade Federal de Mato Grosso do Sul, Chapadão do Sul, Brasil - rcmp92@hotmail.com

vi Universidade Federal de Mato Grosso do Sul, Chapadão do Sul, Brasil - wesley_gomes00@hotmail.com
} 


\section{INTRODUCTION}

The Cerrado is a biome that has suffered the second most from changes caused by human occupation, behind only the Atlantic Forest (MMA, 2011). The degradation to which it is submitted is mainly due to activities such as agricultural frontier expansion, inadequate soil management (PEREIRA et al., 2012) and predatory exploitation of firewood for coal production (MMA, 2011). These activities result in suppressing the natural vegetation which interferes in the ecological processes of the environment, causing ecosystem imbalance (DUARTE et al., 2017), thus the need for recovering these areas arises.

Until the beginning of the 2000s, reclamation projects of degraded environments were aimed at re-establishing climax stage vegetative structure in an altered environment through planting seedlings, which led to a series of failures (RODRIGUES et al., 2007). Currently, alternatives have been pursued for restoring these areas, where the management and induction of ecological processes such as the successional process are recommended, taking advantage of or stimulating ecosystem resilience (CAVA et al, 2016; MARTINS et al., 2008) in order to restore biologically viable forests that do not depend on constant human interventions (BRANCALION et al., 2010). Thus, several models and techniques have been tested to promote restoration of these environments, such as natural regeneration (BRITO et al., 2019), seed mixing (BENINI et al., 2016), no-tillage (PARRON et al., 2015; FERREIRA et al., 2016), planting in rows (ALMEIDA, 2016), planting seedlings (GUIMARAES et al., 2017), the use of integrated cultivation systems (MICOLLIS et al., 2016) and the nucleation strategy (MORES AND BOBROWAKI, 2018). However, many experiments have not yet achieved the desired results, demonstrating that studies in this area still require advancement (BRANCALION et al, 2010).

The complexity related to the succession process, the time required for it to occur, the diversity of ecosystems and degradation histories, as well as the environmental characteristics of the degraded areas make each restoration process unique, and he success of this process depends on the barriers encountered in each 
location (DURIGAN et al., 2010; GOMES et al., 2013; HOLL AND AIDE, 2011; RODRIGUES et al., 2020).

In degraded ecosystems which present low resilience, natural vegetation recovery can be very slow, contributing to the continuity of degradation. Thus, planting species from different successional stages can accelerate the succession process (DUBOC AND GUERRINI, 2007; REZENDE et al., 2015).

Planting seedlings is considered a costly technique due to the implantation cost and initial maintenance of these plantations (BENDITO et al., 2018; GOMES et al., 2013). However, it can be efficient and present faster results when compared to other techniques favouring fast soil cover (RIBEIRO et al., 2012), being the most used technique in the cerrado biome (RODRIGUES et al., 2020). For this, a successional model can be adopted where the cover group provides rapid area closure in the initial succession stage, thus providing conditions for the diversity group formed by the final succession species to establish later (MARTINS, 2009) in places where (in principle) there are barriers to their development (FERREIRA et al., 2010). Therefore, promoting soil cover with native species of the ecosystem itself enables ecological processes to resume, thereby restoring part of the local biodiversity and enabling greater action effectiveness (OLIVEIRA et al., 2015).

The use of Cerrado species in restoring degraded areas is relatively recent (SAMPAIO AND PINTO, 2007). Thus, identifying species capable of developing in these areas becomes essential for managing restorations under ecological and economic criteria (MELO et al., 2004).

It is now known that not all planted species can establish in an area, since they do not survive or form a stable population and therefore do not persist over time (DURIGAN et al., 2010). In order to be successful in establishing species with rapid soil recovering in the cerrado area, it is necessary to introduce species that present high height increase and survival rate values (SAMPAIO AND PINTO, 2007; OLIVEIRA et al., 2015).

In this sense, Durigan (1990) tested 20 species and pointed to Anadenanthera falcata, Tapirira guianensis and Calophyllum brasiliense as promising species for the 
recovery of riparian forest in a cerrado area based on a survival rate above $90 \%$ and a vigorous growth rate; a result attributed to the ecological classification of the species as pioneers and early secondary. In addition, the canopy cover of a stand is an important indicator of the environmental changes that occur in the forest, since it changes the internal environment of these areas, affecting seedling establishment and growth, the floristic structure of the area and the chemical, biological, and physical characteristics of the soil (MELO et al., 2007).

Studies related to the establishment and growth of native cerrado species in degraded areas are still scarce. Thus, this study had the objective to evaluate the initial growth and crown cover of native cerrado species belonging to different successional groups in a forest restoration plantation.

\section{MATERIAL AND METHODS}

The experimental area is located in the municipality of Chapadão do Sul, MS, within the Pasto Ruim microbasin, which has an area of approximately 30,000 ha, presenting degradation processes in all its extension, located at the coordinates $18^{\circ}$ $48^{\prime}$ south latitude and $52^{\circ} 37^{\prime} \mathrm{W}$ longitude, at an average altitude of $860 \mathrm{~m}$. According to the Köppen classification, the climate of the region is tropical with dry season in winter and rainy in summer (Aw), an average annual temperature of 13 to $28^{\circ} \mathrm{C}$ and average annual rainfall of 1,800 mm (CUNHA et al., 2013).

The restoration experiment was installed in February of 2013, in an area of approximately one hectare, using seedling planting based on ecological succession models as the recovery method. The experiment implemented a randomized block design in a factorial scheme with time subdivided plots. Species and ecological groups were considered in the plots and time in the subplot, with three repetitions. Seedlings of 29 native cerrado tree species were produced from seeds collected from selected matrix trees in the region.

Twelve species were selected for this study, four from each of the ecological groups: pioneers, early secondary and late secondary (Table 1). The definition of the 
species to be used in the experiment, considered those of easy occurrence in the study environment.

Diameter at soil height (DSH) and total height (HT) were measured at 8, 14, 20 and 26 months after planting. The crown diameter of the 12 species was obtained at the age of 26 months, in the planting line direction (LD) and in the planting between lines direction (ILD).

Based on the collected data, we calculated the periodic increment in height $\left(\mathrm{PI}_{\mathrm{HT}}\right)$ and diameter at soil height $\left(\mathrm{PI}_{\mathrm{DSH}}\right)$ by species, group and age for the periods of 814, 14-20, 20-26 months after planting, and the crown cover area for species, group and age at 26 months after planting.

A statistical analysis was performed comparing the means obtained by the Tukey test at $5 \%$ probability.

Table 1 - Species selected for study, their respective families and successional groups (Sg). (Pioneers: P; Early secondary: ES; Late secondary: LS)

\begin{tabular}{cccc}
\hline Species & Scientific Name & Family & Sg \\
\hline Angico & Anadenanthera falcata (Benth.) Speg. & Fabaceae & P \\
Baru & Dipteryx alata Vog. & Fabaceae & SI \\
Chichá & Sterculia striata A. St.-Hil. \& Naudin & Malvaceae & SI \\
Cedro & Cedrela fissilis Vell. & Meliaceae & ST \\
Copaíba & Copaifera langsdorfii Desf. & Fabaceae & ST \\
Ipê branco & Handroanthus roseo-albus (Ridl.) Mattos & Bignoniaceae & ST \\
Ipê verde & Cybistax antisyphilitica (Mart.) Mart. & Bignoniaceae & P \\
Jacarandá do campo & Platypodium elegans Vogel & Fabaceae & P \\
Jatobá do cerrado & Hymenaea courbaril L. & Fabaceae & ST \\
Marmelada de & Alibertia edulis (Rich.) A. Rich. & Rubiaceae & SI \\
bezerro & Enterolobium contortisiliquum (Vell.) Morong & Fabaceae & SI \\
Orelha de negro & Samanea tubulosa (Benth.) Barneby \&J. W. & Fabaceae & $\mathrm{P}$ \\
Sete cascas & Grimes & \\
\hline
\end{tabular}

\section{RESULTS AND DISCUSSION}

Analyzing the rainfall regime, it was observed that the months from January to April, were the ones that showed greater stability and greater monthly accumulations 
for the three years of study. The total accumulation in the four months was 264,672 and $812.2 \mathrm{~mm}$ for the years 2013, 2014 and 2015, respectively (Fig. 1).

Figure 1. Mean monthly precipitation during the study period for the municipality of Chapadão do Sul, MS

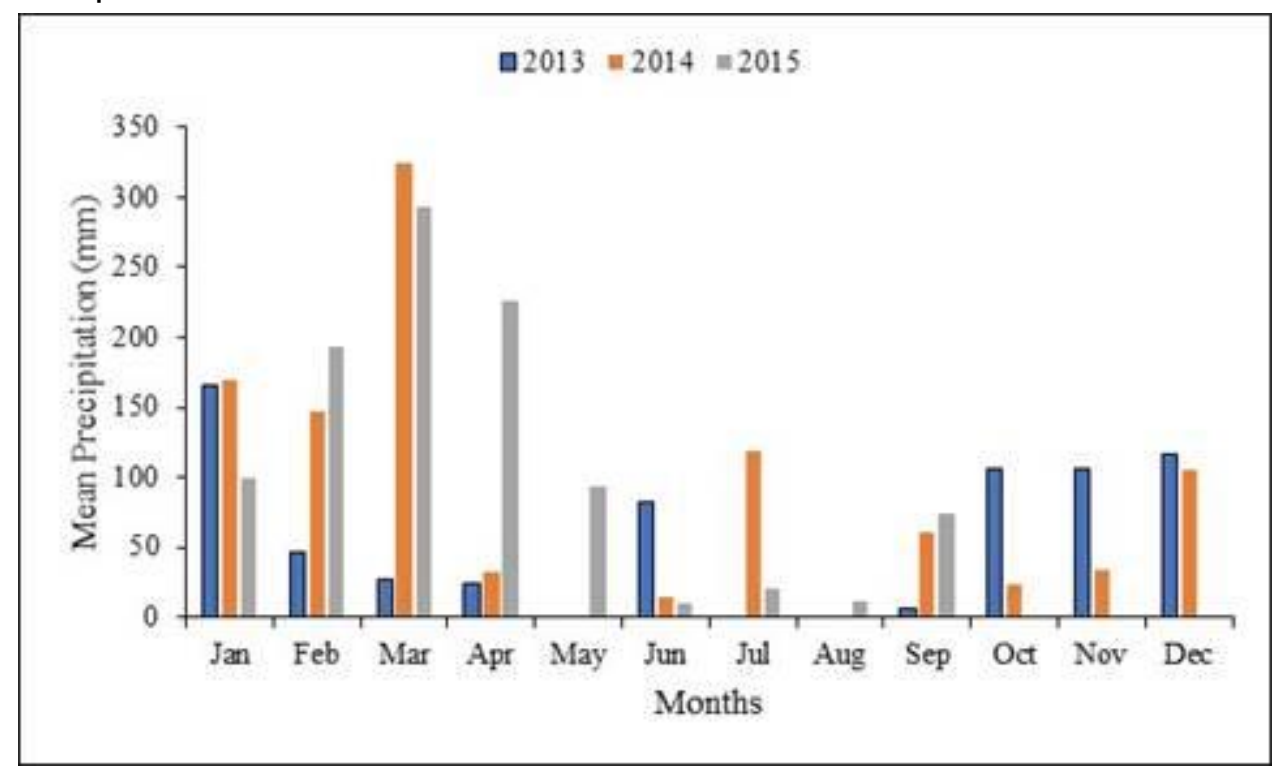

Source: by the authors

The increase in diameter and height of the cerrado species evaluated varied with the ecological group to which they belonged and the evaluation period (Table 2). Between 8 and 14 months and 20 to 26 months of age, periods equivalent to the interval of months between October and April (and the time of the year that corresponds to the highest occurrence of rainfall in the region - Figure 1), the pioneer species group presented the greatest growth in the evaluated variables, while those in the late secondary group presented the lowest growth. A similar result was observed in studies by Duboc and Guerrini (2007) and Leles et al. (2011), where the average diameter growth was higher for the pioneer species than the non-pioneer species. According to Martins (2009), one of the outstanding characteristics of the species belonging to the pioneers group is the rapid initial growth when compared to the group of late secondary species, since these are less demanding to soil fertility and can develop in adverse conditions. 
Table 2 - Periodic increment in diameter at soil height ( $\left.\mathrm{Pl}_{\mathrm{DSH}}\right)$ and total height $\left(\mathrm{PI}_{\mathrm{HT}}\right)$ for the three successional groups in the periods of 8-14 months, 14-20 months and 20-26 months

\begin{tabular}{ccccccc}
\hline & \multicolumn{7}{c}{ Evaluation Period } \\
\cline { 2 - 7 } Sg & $8-14$ & $14-20$ & $20-26$ & $8-14$ & $14-20$ & $20-26$ \\
& $0.32 \mathrm{a}$ & $0.29 \mathrm{~b}$ & $0.82 \mathrm{a}$ & $20.98 \mathrm{a}$ & $12.47 \mathrm{~b}$ & $24.27 \mathrm{a}$ \\
$\mathrm{PI}$ & $0.26 \mathrm{~b}$ & $0.44 \mathrm{a}$ & $0.74 \mathrm{~b}$ & $14.69 \mathrm{~b}$ & $14.65 \mathrm{a}$ & $18.00 \mathrm{~b}$ \\
$\mathrm{ST}$ & $0.13 \mathrm{c}$ & $0.13 \mathrm{c}$ & $0.58 \mathrm{c}$ & $7.31 \mathrm{c}$ & $7.14 \mathrm{c}$ & $15.25 \mathrm{c}$ \\
\hline
\end{tabular}

Values followed by the same letter in the column do not differ at the $5 \%$ probability level by the Tukey test; (Sg): successional groups; P: pioneers; ES: early secondary; LS: late secondary.

Between the ages of 14 and 20 months, which corresponded to the interval between April and October 2014 when the rains were sporadic or did not occur in the study region (Figure 1), the early secondary group presented the greatest increase in diameter and height, while the late secondary group presented the smallest increases. When compared to the group of pioneers, these values were $51.7 \%$ higher in $\mathrm{Pl}_{\mathrm{DSH}}$ and $17.5 \%$ in $\mathrm{Pl}_{\mathrm{HT}}$, and this difference was even more significant when compared to the late secondary group, being $238 \%$ higher in diameter and $105 \%$ in height (Table 2).

The higher increment of early secondary in the second evaluation period (14-20 months) seems to indicate that they can grow better in adverse conditions, especially in periods without rain, as occurs in the study region (Figure 1). Or, pioneers may be able to reduce their growth rate in adverse periods as a strategy to survive those periods. According to Kanegae et al. (2000), an adaptation form of young Cerrado species would be to go into dormancy and/or maintain photosynthesis at lower rates under the reduced leaf water potential to survive the dry season.

The species within each successional group varied in diameter and height for the three evaluated periods (Table 3). All species of the three groups studied presented the largest diameter increases in the period from 20 to 26 months of age, demonstrating a diametric growth relationship with soil water availability. According to Zanon and Finger (2010), both excess and water deficiency may lead to a reduction in the photosynthetic rate of plants. For Martinkoski et al. (2015), this reflects in the exchange rate of tropical species. 
Table 3 - Periodic increment in diameter at soil height $\left(\mathrm{Pl}_{\mathrm{DSH}}\right)$ and total height $\left(\mathrm{PI}_{\mathrm{HT}}\right)$, for the studied species within the successional groups in the periods of 8-14 months, 1420 months and 20-26 months

\begin{tabular}{|c|c|c|c|c|c|c|}
\hline \multirow{3}{*}{ Sg } & \multicolumn{6}{|c|}{ Evaluation Period } \\
\hline & \multicolumn{3}{|c|}{$\mathrm{Pl}_{\mathrm{DSH}(\mathrm{cm})}$} & \multicolumn{3}{|c|}{$\mathrm{Pl}_{\mathrm{HT}(\mathrm{cm})}$} \\
\hline & $8-14$ & $14-20$ & $20-26$ & $8-14$ & $14-20$ & $20-26$ \\
\hline \multicolumn{7}{|c|}{ Pioneers } \\
\hline Af & $0.34 \mathrm{bB}$ & $0.23 \mathrm{bC}$ & $1.30 \mathrm{aA}$ & $36.43 \mathrm{aB}$ & $16.52 \mathrm{bC}$ & $37.30 \mathrm{aA}$ \\
\hline $\mathrm{Ca}$ & $0.10 \mathrm{dC}$ & $0.15 \mathrm{cB}$ & $0.51 \mathrm{dA}$ & $12.79 \mathrm{cA}$ & $6.61 \mathrm{cB}$ & $6.14 \mathrm{~dB}$ \\
\hline $\mathrm{Pe}$ & $0.31 \mathrm{cC}$ & $0.55 \mathrm{aB}$ & $0.87 \mathrm{bA}$ & $31.84 \mathrm{bA}$ & $23.38 \mathrm{aB}$ & $19.64 \mathrm{cC}$ \\
\hline St & $0.53 \mathrm{aB}$ & $0.23 \mathrm{bc}$ & $0.60 \mathrm{cA}$ & $2.85 \mathrm{~dB}$ & $3.39 \mathrm{~dB}$ & $34.01 \mathrm{bA}$ \\
\hline \multicolumn{7}{|c|}{ Early secondary } \\
\hline $\mathrm{Da}$ & $0.18 \mathrm{cC}$ & $0.18 \mathrm{~dB}$ & $0.95 \mathrm{bA}$ & $10.78 \mathrm{cB}$ & $4.47 \mathrm{dC}$ & $38.89 \mathrm{aA}$ \\
\hline $\mathrm{Ae}$ & $0.19 c C$ & $0.46 \mathrm{bB}$ & $0.50 \mathrm{cA}$ & $11.19 \mathrm{cC}$ & $12.01 \mathrm{bB}$ & $13.78 \mathrm{bA}$ \\
\hline Ss & $0.30 \mathrm{bB}$ & $0.21 \mathrm{cC}$ & $0.32 \mathrm{dA}$ & $13.36 \mathrm{bA}$ & $9.67 c B$ & $10.24 \mathrm{cB}$ \\
\hline Ec & $0.37 \mathrm{aC}$ & $0.90 \mathrm{aB}$ & $1.18 \mathrm{aA}$ & $23.42 \mathrm{aB}$ & $32.44 \mathrm{aA}$ & $13.06 \mathrm{bc}$ \\
\hline \multicolumn{7}{|c|}{ Late secondary } \\
\hline $\mathrm{Hs}$ & $0.18 \mathrm{aB}$ & $0.13 \mathrm{bC}$ & $0.46 \mathrm{cA}$ & $9.07 \mathrm{aB}$ & $3.50 \mathrm{cC}$ & $24.30 \mathrm{aA}$ \\
\hline $\mathrm{Cl}$ & $0.11 \mathrm{bB}$ & $0.11 \mathrm{bB}$ & $0.57 \mathrm{bA}$ & $6.14 \mathrm{cC}$ & $7.86 \mathrm{bB}$ & $11.79 \mathrm{cA}$ \\
\hline $\mathrm{Cf}$ & $0.09 \mathrm{bB}$ & $0.10 \mathrm{bB}$ & $0.88 \mathrm{aA}$ & $6.78 \mathrm{bC}$ & $9.78 \mathrm{aB}$ & $17.59 \mathrm{bA}$ \\
\hline $\mathrm{Hr}$ & $0.16 \mathrm{aC}$ & $0.19 \mathrm{aB}$ & $0.40 \mathrm{dA}$ & 7.24 bA & 7.42 bA & $7.34 \mathrm{dA}$ \\
\hline
\end{tabular}

Values followed by the same lowercase letter in the column and upper case in the row do not differ at the $5 \%$ probability level by the Tukey test; Sp - species: Af - angico; Ca - ipê verde; Pe - jacarandá; St - sete cascas; Da - baru; Ae - marmelada; Ss - chichá; Ec orelha-de-negro; Hs - jatobá; Cl - copaíba; Cf - cedro; Hra - ipê-branco.

Within the successional groups studied, the growth for the height variable varied over the evaluation time. In the pioneers group, angico presented higher $\mathrm{Pl}_{\mathrm{HT}}$ in the last evaluated period, followed by the first evaluation period, which both coincide with the rainy season in the region (Figure 1). This reduced its rate of growth in the dry period of the year (14-20 months) (Table 3). On the other hand, the ipê verde and the jacarandá-do-campo had a higher growth in the first evaluated period. This shows that even though they belong to the same successional group, the species present different establishment strategies in the field. According to Venturoli et al. (2013), the different behavior in relation to the growth in height and diameter of the plants may be related to the growth rate that each species presents.

Species in the initial secondary group also presented differentiated behavior regarding height increase (Table 3). Baru and marmelada-de-bezerro presented the highest growth in the period from 20 to 26 months, while the orelha-de-negro showed the highest $\mathrm{Pl}_{H T}$ in the second evaluation period, which coincides with the dry period 
of the year. The chichá presented a reduced growth rate in the dry period (14-20 months) for both diameter and height. In following the growth of different Cerrado species in degraded areas, Oliveira et al. (2015) also found different growth strategies among evaluated species which belonged to different cerrado environments, as well as within each environment.

Regarding the height variable for the late secondary group, copaiba and cedro had similar behavior for PIDSH (Table 3), while ipê branco showed a different growth strategy at the same time, maintaining the same growth rate during the evaluated period since there were no significant differences between the evaluated periods for this species. In this group, only jatobá-do-cerrado species showed a lower growth rate in the period of 14 to 20 months for both height and diameter. This reduction may be related to the period of the year in which the evaluations were carried out (AprilOctober) as there is a decrease in rainfall in the region. According to Martinkoski et al. (2015), this variation in the species growth may be related to the local abiotic characteristics and/or to the genetic factors of each species, thus being determinant in the species development.

When evaluating the $\mathrm{PI}_{\mathrm{DSH}}$ and $\mathrm{PI}_{\mathrm{HT}}$ among the species within the successional groups (Table 3), it can be observed that the species present a different growth rate among them. Among the pioneers, ipê verde presented the smallest growth rate in diameter in all the evaluation periods. This species was only ahead of the sete cascas species for height in the first two periods evaluated. Between 8 and 14 months after planting, the sete cascas presented the highest $\mathrm{Pl}_{\mathrm{DSH}}$, which was $56 \%$ higher than angico and $430 \%$ higher than ipê verde.

For height, the angico species presented the greatest increment in this period, with this value being $14.4 \%$ superior to the $\mathrm{PI}_{\mathrm{HT}}$ observed for the jacarandá-do-campo and 12.8 times greater than that observed for sete cascas. This shows that species vary in their initial investment in height or diameter growth, establishing different establishment strategies in the field, even belonging to the same successional group. According to Oliveira et al. (2015) typical cerrado species of different environments (savanna and forest) present different initial growth strategies. In their study, savanna 
species initially invested more in diametric growth, while those in the forest environment invested more in height. Therefore, species such as angico, which occur naturally in forests, invest in height first as a way of establishing themselves in the canopy.

In the period from 14 to 20 months, the driest period of the year in the region (April/September), the species with the highest $\mathrm{PI}_{\mathrm{DSH}}$ and $\mathrm{PI}_{\mathrm{HT}}$ was the jacarandá-docampo (Table 3). Species that occur in drier environments, preferably in the Cerrado in a restricted sense (OLIVEIRA et al., 2015; ALVES et al., 2016), may present a mechanism for avoiding drought, since they did not interrupt their development in this season. In the third period of 20 to 26 months, the angico species presented the greatest increases for both diameter and height, while the smallest increase $\left(\mathrm{PI}_{\mathrm{DSH}}\right.$ and $\mathrm{PI}_{\mathrm{HT}}$ ) was observed for the ipê verde.

Baru and marmelada-de-bezerro were the species that presented the smallest increment for the initial secondary group in the period of 8 to 14 months (Table 3 ) for both height and stem diameter, and did not differ significantly between them. The orelha-de-negro was the one that presented the largest increments in diameter in all periods. However, baru presented the greater increase among the others only for height in the period of 20 to 26 months.

In the late secondary group for the period of 8-14 months, the jatobá-docerrado and ipê branco were the species with the highest $\mathrm{Pl}_{\mathrm{DSH}}$, obtaining on average 70\% higher than the copaiba and cedro species, which had obtained smaller increases. Regarding $\mathrm{Pl}_{\mathrm{HT}}$ for the same period, jatobá obtained the greatest increase, being 40.4\% higher than what was observed for the copaiba and cedro species which obtained the smallest increases. In the period of 14-20 months, ipê branco was the only species that differed from the others with an average of $68 \%$ higher diameter increase than the others. The cedro species obtained the greatest increment at the same time and for the same period, being 179\% superior to jatobá, which presented the smallest increase. For the period of 20-26 months, the cedro species had the highest $\mathrm{Pl}_{\mathrm{DSH}}$, while the ipê branco species presented the lowest $\mathrm{Pl}_{\mathrm{DSH}}$, with cedro being $120 \%$ higher than ipê branco. 
The crown projection area of the studied species varied among the successional groups. The largest crown areas were observed for the pioneers group, while the smallest areas were verified for species of the most advanced succession stage (Figure 2).

Figure 2 - Crown projection area for the three successional groups studied at 26 months of age.

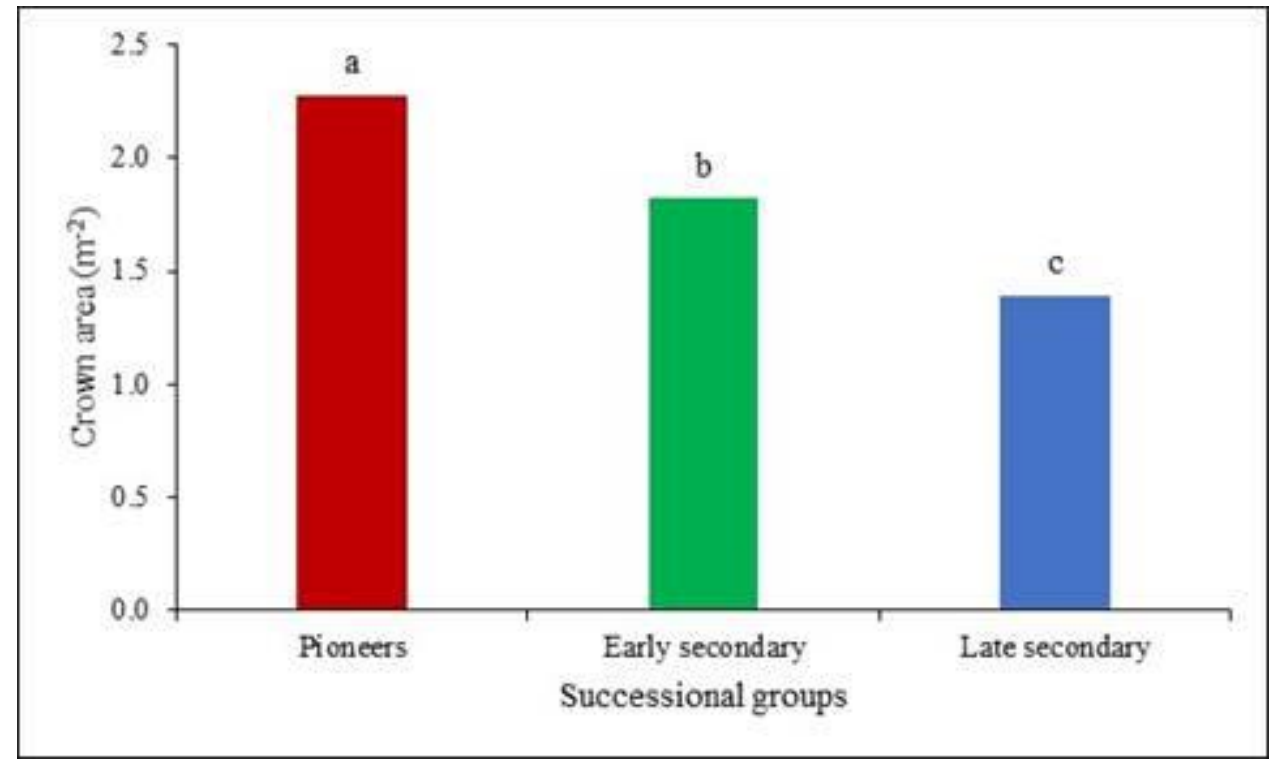

This result is due to the characteristics attributed to these successional groups, since the pioneer species present rapid growth and expansion of their crowns among their main characteristics in order to provide shading, assisting in controlling intercanopy competition, providing soil protection and favorable microclimatic conditions for end-of-succession species to be established later (MELO et al., 2007; PEREIRA et al., 2012). It is also worth mentioning that the small development of the leaf area of the late secondary group species can be caused by the soil characteristics and the influence of the local agents (PEREIRA et al., 2012), since they are generally plants which are more demanding of the soil characteristics (MARTINS, 2009).

In analyzing the species within each group, it can be observed that there is a variation in crown development between the species of the same group (Figure 3). The species that stood out for the pioneers group was jacarandá-do-campo $\left(3.57 \mathrm{~m}^{2}\right)$ followed by angico $\left(3.20 \mathrm{~m}^{2}\right)$, while the smallest crown area was for ipê verde $\left(0.31 \mathrm{~m}^{2}\right)$. 
Among the early secondary species, orelha-de-negro stood out from the others with a mean area of $3.13 \mathrm{~m}^{2}$, being $92 \%$ larger than the baru species $\left(1.63 \mathrm{~m}^{2}\right)$, which was the second largest in crown area. In the late secondary group, the cedro species had the largest crown area $\left(3.47 \mathrm{~m}^{2}\right)$, which was $689 \%$ higher than the jatobá and ipê branco species, which obtained the smallest areas at 26 months of age. This variation found among the species once again demonstrates that local biotic and abiotic factors as well as characteristics inherent to each species may interfere with their development (BINOTTO et al., 2016; MARTINKOSKI et al., 2015).

Figure 3. Crown projection area for species within the three studied successional groups at 26 months of age.

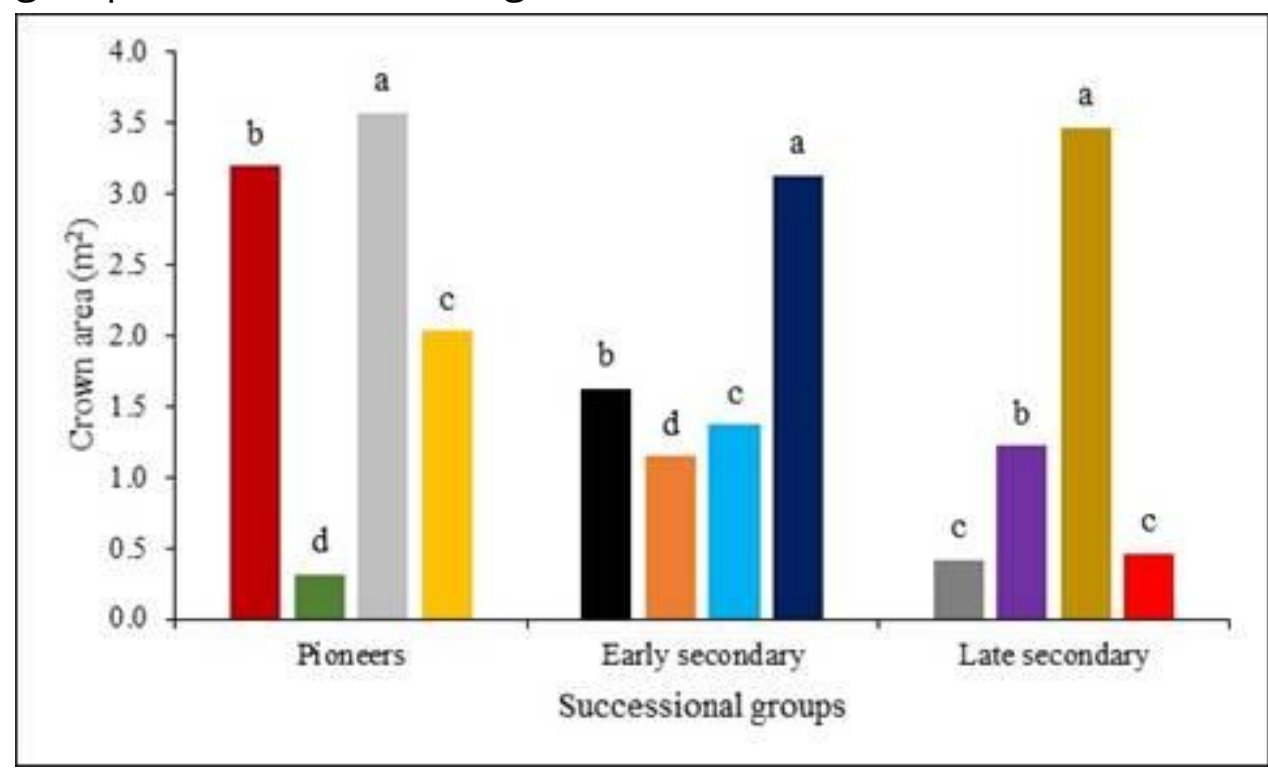

Pioneers

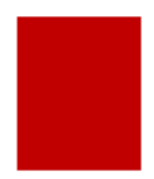

Angico

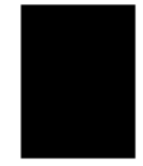

Early secondary

Baru

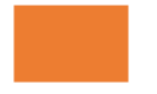

Marmelada

Ipê verde

Jacarandá

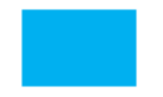

Chichá

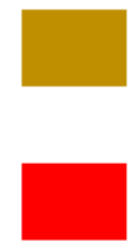

Late secondary

Jatobá do cerrado
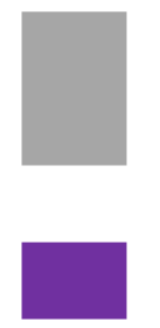

Copaíba

Cedro

Ipê branco 
The work made it possible to verify that the species of the successional group of the pioneers have a quick response regarding growth and the formation of canopy, when the climatic conditions are more favorable. In this way, they are able to establish themselves more efficiently and provide adequate conditions for the other successional groups. Thus, the pioneers manage to restrict their energy cost during the most stressful period, preserving themselves for other times more conducive to their development. In the unfavorable climatic period, mainly due to the reduction of precipitation, the initial secondary ones show an outstanding growth.

Regarding the species used, it was possible to observe an intense variation by species in the responses to growth in height, diameter and crown, for all successional groups. This aspect reinforces the need to establish more studies to define the best genetic materials for different environments within the same biome. The main starting point would be the native species of the environment itself, however, it is not always possible to follow these parameters, for different reasons, such as the absence of natural vegetation, lack of phytosociological studies, precariousness in the production of seedlings, among others.

The information provided by the study in question, facilitates decision-making in the restoration process, and configures greater certainty in the desired results. Some points are clearer and can guide the implementation of the system. The success in this establishment will provide ecological benefits to the system and the favored region, allowing the faster covering of the soil, which reduces erosion processes, and consequently, physical, chemical and biological losses in the environment. It also favors the initial restoration of fauna, which will contribute to the acceleration of the restoration process. In this respect, the use of attractive species, such as fruit trees, can be advantageous. 


\section{CONCLUSIONS}

The pioneer and early secondary successional groups presented the largest increases in height and diameter at soil height up to 26 months of age, while the late secondary group presented the smallest increments.

The species within each successional group vary as to their initial investment in growth in height and in diameter at soil height, implementing different establishment strategies in the field.

The crown area varied between the successional groups. The pioneers group presented the largest crown areas, while the late secondary group had smaller crown areas.

The work allowed us to understand that the establishment of the species of the successional group of the pioneers should preferably be at the beginning of the rainy season, so that they take advantage of the greater availability of water, which was a favorable point for the growth of these species. The variation in species responses, allows us to understand that the definition of which will be used must be based on previous studies. Priority should also be given to studies of this nature in the different biomes and in different environments within the biomes, so that the information is more specific and facilitates the ecological establishment of the environments to be restored.

\section{ACKNOWLEDGMENTS}

Support from the Universidade Federal de Mato Grosso do Sul.

This study was financed in part by the Coordenação de Aperfeiçoamento de Pessoal de Nível Superior - Brasil (CAPES) - Finance Code 001.

\section{REFERENCES}

ALMEIDA DS. Recuperação Ambiental da Mata Atlântica. Ilhéus: Editus, 2016. 200p.

ALVES LR, OLIVEIRA RJ, COIMBRA RR, FERREIRA WM. Crescimento inicial de Parkia platycephala (Benth.) e Enterolobium timbouva (Mart.) sob condições de campo numa área de Cerrado.

Revista Ceres. 2016; 63(2): 154-164. 
BENDITO BPC, SOUZA PA, FERREIRA RQS, CÂNDIDO JB, SOUZA PB. Espécies do cerrado com potencial para recuperação de áreas degradadas, Gurupi (TO). Revista Agrogeoambiental. 2018; 10(2): 99-110.

BENINI R. et al. Manual de Restauração da vegetação nativa, Alto Teles, MT. Alta Floresta: The Nature Conservancy. 2016. 13

BINOTTO B., ANTONIAZZI AP, NEUMANN GM, SAUSEN TL, BUDKE JC. Tolerância de plântulas de Cedrela fissilis Vell. a diferentes amplitudes e intensidades de inundação. Ciência Florestal. 2016; 26(4): 1339-1348.

BRANCALION PHS, RODRIGUES RR, GANDOLFI S, KAGEYAMA PY, NAVE AG, GANDARA FB, BARBOSA LM, TABARELLI M. Instrumentos legais podem contribuir para a restauração de florestas tropicais biodiversas. Revista Árvore. 2010; 34(3): 455-470.

BRITO CN, PEREIRA AP, VENTUROLI F. Estimativa de biomassa da regeneração natural de uma área de cerradão em Niquelândia, Goiás. Revista Tree Dimensional - ProFloresta. 2019; 4(7): 18-24.

CAVA MGB, ISERNHAGEN I, MENDONÇA AH, DURIGAN G. Comparação de técnicas para restauração da vegetação lenhosa de cerrado em pastagens abandonadas. Hoehnea. 2016; 43(2): 301-315.

CUNHA FF, MAGALHÃES FF, CASTRO MA. Métodos para estimativa da evapotranspiração de referência para Chapadão do Sul - MS. Engenharia na Agricultura. 2013; 21: 159-172.

DUARTE TEP, ANGEOLETTO FHS, SANTOS JWMC, LEANDRO DS, BOHRER JFC, VACCHIANO MC, LEITE LB. O papel da cobertura vegetal nos ambientes urbanos e sua influência na qualidade de vida nas cidades. Desenvolvimento em questão. 2017; 15(40): 175-203.

DUBOC E, GUERRINI IA. Crescimento inicial e sobrevivência de espécies florestais de matas de galeria no domínio do cerrado em resposta à fertilização. Energia Agrícola. 2007; 22(1): 4260 .

DURIGAN G. Taxa de sobrevivência e crescimento inicial das espécies em plantio de recomposição da mata ciliar. Acta Botânica Brasílica. 1990; 4(2): 35-40.

DURIGAN G, ENGEL VL, TOREZAN JM, MELO ACG, MARQUES MCM, MARTINS SV, REIS A, SCARANO F R. Normas jurídicas para a restauração ecológica: uma barreira a mais para dificultar o êxito das iniciativas? Revista Árvore. 2010; 34(3): 471-485.

FERREIRA EM, ANDRAUS MP, CARDOSO AA, COSTA LFS, LOBO LM, LEANDRO WM. Recuperação de áreas degradadas, adubação verde e qualidade da água. Revista Monografias Ambientais. 2016; 15(1): 228-246.

FERREIRA WC, BOTELHO AS, DAVIDE AC, FARIA JMR, FERREIRA DF. Regeneração natural como indicador de recuperação de área degradada a jusante da usina hidrelétrica de Camargos, MG. Revista Árvore. 2010; 34(4): 651-660.

GOMES EPC, SUGIYAMA M, ADAMS C, PRADO HM, OLIVEIRA JUNIOR CJF. A sucessão florestal em roças em pousio: a natureza está fora da lei? Scientia Forestalis. 2013; 41(99): 343-352. 
GUIMARÃES LAOP, ASSIS IR, DIAS LE, CORDEIRO AL, FREIRE AS. Espécies arbóreas potenciais para a revegetação de rejeito salino contaminado com arsênio. Ciência Florestal. 2017; 27(3): 871-881.

HOLL KD, AIDE TM. When and where to actively restore ecosystems? Forest Ecology and Management. 2011; 261(10): 1558- 1563.

KANEGAE M, BRAZ V, FRANCO AC. Efeitos da seca sazonal e da disponibilidade de luz na sobrevivência e crescimento de Bowdichia virgilioides em duas fitofisionomias típicas dos cerrados do Brasil Central. Revista Brasileira de Botânica. 2000; 23(4): 457-466.

LELES PSS, ABAURRE GW, ALONSO JM, NASCIMENTO DF, LISBOA AC. Crescimento de espécies arbóreas sob diferentes espaçamentos em plantio de recomposição florestal. Scientia Forestalis. 2011; 39(90): 231-239.

MARTINKOSKI L, VOGEL GF, JADOSKI SO. Influência do clima no crescimento diamétrico de Araucaria angustifolia: revisão bibliográfica. Brazilian Journal of Applied Technology for Agricultural Science. 2015; 8(2): 104-111.

MARTINS SV, ALMEIDA D.P, FERNANDES LV, RIBEIRO TM. Banco de sementes como indicador de restauração de uma área degradada por mineração de caulim em Brás Pires, MG. Revista Árvore. 2008; 32(6): 1081-1088.

MARTINS SV. Recuperação de áreas degradadas: ações em áreas de preservação permanente, voçorocas, taludes rodoviários e de mineração. Viçosa: Aprenda Fácil; 2009. $270 p$.

MELO ACG, DURIGAN G, KAWABATA M. Crescimento e sobrevivência de espécies arbóreas plantadas em área de Cerrado, Assis - SP. In: BOAS OV, DURIGAN G. Pesquisas em conservação e recuperação ambiental no oeste paulista: resultados da cooperação Brasil/Japão. São Paulo: Páginas \& Letras; 2004. p. 315-324.

MELO ACG, MIRANDA DLC, DURIGAN G. Cobertura de copas como indicador de desenvolvimento estrutural de reflorestamentos de restauração de matas ciliares no médio vale do Paranapanema, SP, Brasil. Revista Árvore. 2007; 31(2): 321-328.

MICCOLIS A, PENEIREIRO FM, MARQUES HR, VIEIRA DLM, ARCO-VERDE MF, HOFFMANN MR, REHDER T, PEREIRA AVB. Restauração ecológica com sistemas agroflorestais: como conciliar conservação com produção: opções para Cerrado e Caatinga. Brasília: Embrapa Cerrados. 2016. 266p.

MINISTÉRIO DO MEIO AMBIENTE - MMA. Monitoramento do desmatamento nos biomas brasileiros por satélite. Brasília: MMA/IBAMA; 2011. 65p.

MORES GJ, BOBROWAKI R. Efeitos da presença e distância de poleiros artificiais na dispersão de sementes de uma área degradada em Irati, Paraná. Acta Biológica Catarinense. 2018; 5(2): 106-117.

OLIVEIRA MC, RIBEIRO JF, PASSOS FB, AQUINO FG, OLIVEIRA FF, SOUSA SR. Crescimento de espécies nativas em um plantio de recuperação de Cerrado sentido restrito no Distrito Federal, Brasil. Revista Brasileira de Biociências. 2015; 13(1): 25-32. 
PARRON LM, GARCIA JR, OLIVEIRA EB, BROWN GG, PRADO RB (eds.). Serviços ambientais em sistemas agrícolas e florestais do Bioma Mata Atlântica. Brasília: Embrapa. 2015. 374p.

PEREIRA JS, ABREU CFNR, PEREIRA RA, RODRIGUES SC. Avaliação do índice de sobrevivência e crescimento de espécies arbóreas utilizadas na recuperação de área degradada. Revista Geonorte. 2012; 1(4): 138-148.

RESENDE LA, PINTO LVA, SANTOS EC, SILVA S. Crescimento e sobrevivência de espécies arbóreas em diferentes modelos de plantio na recuperação de área degradada por disposição de resíduos sólidos urbanos. Revista Árvore. 2015; 39(1): 147-157.

RODRIGUES ABM, GIULIATTI NM, PEREIRA JUNIOR A. Aplicação de metodologias de recuperação de áreas degradadas nos biomas brasileiros. Brazilian Applied Science Review. 2020; 4(1): 333-369.

RODRIGUES RR, GANDOLFI S, NAVE AG, ATTANASIO CM. Atividades de adequação ambiental e restauração florestal do LERF/ESALQ/USP. Pesquisa Florestal Brasileira. 2007; 55: 7-21.

RIBEIRO PRCC, RIBEIRO JJ, SANTOS NETO AR, ROCHA JRP, CORTE IS. Métodos de recuperação de mata ciliar como proposta de Recuperação de nascentes no cerrado. Enciclopédia Biosfera. 2012; 8(15): 1866-1882.

SAMPAIO JC, PINTO JRR. Critérios para avaliação do desempenho de espécies nativas lenhosas em plantios de restauração no Cerrado. Revista Brasileira de Biociências. 2007; 5(1): 504506.

VENTUROLI F, VENTUROLI S, BORGES JD, CASTRO DS, SOUZA DM, MONTEIRO MM, CALIL FN. Incremento de espécies arbóreas em plantio de recuperação de área degradada em solo de cerrado no Distrito Federal. Bioscience Journal. 2013; 29(1) 143-151.

ZANON MLB, FINGER CAG. Relação de variáveis meteorológicas com o crescimento das árvores de Araucaria angustifolia (Bertol.) Kuntze em povoamentos implantados. Ciência Florestal. 2010; 20(3): 467-476. 